\title{
TNFRSF12A Gene
}

National Cancer Institute

\section{Source}

National Cancer Institute. TNFRSF12A Gene. NCI Thesaurus. Code C117071.

This gene is involved in signal transduction and the promotion of ang iogenesis. 